\title{
ETHNOBIOLOGICAL KNOWLEDGE GENERATION DURING “HERDING GAMES" IN PASTORALIST MAASAI SOCIETY (SOUTHERN KENYA)
}

\author{
Xiaojie TIAN*
}

Résumé - Savoir ethnobiologique engendré durant les « jeux de conduite de troupeau » dans la société Maasai pastoraliste (sud Kenya). Cet article explore la production du savoir ethnobiologique relatif au bétail par les enfants Maasai du sud du Kenya, à travers des jeux de conduite de troupeau. Dans la communauté Maasai qui continue à utiliser et à gérer collectivement les terres, les enfants prennent part activement aux tâches quotidiennes liées au bétail, lesquelles servent de cadre à la production du savoir ethnobiologique. Pendant le jeu, les enfants mettent en pratique et communiquent leurs compétences relatives au bétail, tout en les ajustant aux conditions sociales et environnementales actuelles, et en mettant en scène les relations sociales qu'ils découvrent au fil de leurs tâches quotidiennes. L'étude met en lumière la pertinence $\mathrm{du}$ jeu dans la construction du savoir ethnobiologique dans des contextes sociaux pastoraux durant les jeux de bétail. Ce faisant, les enfants contribuent à l'enrichissement des relations homme-bétail-environnement dans la société Maasai actuelle.

Mots clés - Enfants pasteurs; jeu quotidien; apprentissage du savoir ethnobiologique; faire-croire ; culture de pairs

Abstract - This paper explores the generation of livestock-related ethnobiological knowledge of Maasai children in Southern Kenya during their herding games. In the Maasai community where lands are still used and managed communally, children still take active roles in livestock-related daily chores, through which they generate ethnobiological knowledge. During the game, children continue the practice and the communication of livestock-related skills, together with interpretations of current social and natural conditions, and the social relations they had experienced during daily chores. This study highlights the significance of ethnobiological knowledge generation in pastoral social contexts during herding games, through which children enrich the human-livestock-biota relations in current Maasai society.

\footnotetext{
* Xiaojie Tian, Faculty of Health and Sport Sciences, University of Tsukuba, Graduate School of Asian and African Area Studies, Kyoto University, Japan, xiaojie.tian2013@gmail.com
} 
Keywords - Pastoral children; daily play; ethnobiological knowledge learning; make-believe; peer culture

Resumen - Conocimiento etnobiológico generado durante los "juegos de conducta de rebaño" en la sociedad pastoral Maasai (sur de Kenia). Este artículo explora la producción de conocimientos etnobiológicos relacionados con el ganado por parte de los niños Maasai en el sur de Kenia, a través de juegos de pastoreo. En la comunidad Maasai que continua utilizando y gestionando sus tierras colectivamente, los niños participan activamente en las tareas diarias relacionadas con el ganado, que proporcionan un marco para la producción de conocimiento etnobiológico. Durante el juego, los niños siguen practicando la comunicación y las habilidades ganaderas, mientras interpretan las condiciones sociales y ambientales actuales, y retratan las relaciones sociales que descubren a medida que desarrollan su vida cotidiana. El estudio destaca la relevancia del juego en la construcción del saber etnobiológico en un contexto social pastoral durante los juegos de conducta de rebaño. Al hacerlo, los niños contribuyen al enriquecimiento de las relaciones hombre-ganado-medio ambiente en la sociedad Maasai actual.

Palabras claves - Niños pastores; juego cotidiano; aprendizaje del conocimiento etnobiológico; hacer creer; cultura de pares

\section{INTRODUCTION}

\section{The ethnobiological knowledge of East African pastoralists}

SINCE THE LATE 19th century, researchers from the fields of cultural and ecological anthropology, ethnology, and ethnobiology have explored the relationship of pastoralists with their livestock and natural surroundings in East Africa. They documented the pastoral ways of knowing, managing, and utilizing the livestock and natural resources (Bekure et al. 1991; Bussmann et al. 2006; Galaty 1989; Homewood \& Kiringe 2005; Konaka 2010; Little et al. 1999; Ohta 1982, 1984, 1987; Rodgers 1991; Sato 1980;), and explored concurrent strategies that different pastoral groups practiced for coping with social and natural environment changes (Butt 2010, 2011; Konaka 2005; Oba 2012; Sun 2005). These studies contribute to the understanding of ethnobiological knowledge (hereafter referred to as EK) of pastoralists, inside of which, the human/livestock/biota relations crucially influence local perceptions, utilization and management of land, water resources, and plant species, and people's perceptions and ways of coexisting with wildlife (de Pinho 2009; Meguro 2014). The pastoral EK in this study refers to the generative system that 
is embedded in the processes of human-livestock-biota interactions, and developed during daily practices in concurrent social and natural environmental contexts of pastoralists. Local people, including children, know by ways of their practices (Ingold \& Kurttila 2000), "through an ongoing engagement in perception and action, with the constituents of their environment" (Ingold 2011: 159).

Within the studies mentioned above, the livestock-related pastoral EK has generally been discussed in relation to seven types of skills and daily practices: (1) livestock identification and classification; (2) livestock grouping; (3) reproduction control; (4) milking; (5) diseases management; (6) watering; and (7) livestock herding ${ }^{1}$. These skills as practiced by pastoralists reinforce gender and age differences from a young age.

\section{Maasai children's participation in local subsistence}

Spencer (2003) and Grandin (1991) described the gender-age roles in pastoral Maasai society with its age organizations and local labor divisions using the concept of age-grades. There are three male age-grades in Maasai society: boys ilayiok, morans ilmurran, and elders ilpayiani; and two female age-grades: girls ntoyie, and married women intasati. Individuals perform different social roles and participate in the aforesaid seven types of livestock-related daily tasks independently and collaboratively (Grandin 1991). Children who grow up in pastoral societies participate in those subsistence-related activities initiatively and contribute to local wellbeing with the collaboration of adults.

In anthropological studies, several researchers documented the life of children and their social roles in pastoral societies (Casimir 2010; Fratkin 1989; Grandin 1991; Messing 1985; Spencer 2003; Spittler 1998). Spittler (1998) documented the life of Tuarag pastoralist children. He found that children around three years old were given an infant of small stock to care for. These children develop their skills of managing livestock while growing up with their animals. Grandin (1991) found that Maasai children in Kenya participated in livestock tending from an early age. At

\footnotetext{
1 The details of these seven skills and daily practices have been explained in a previous study (Tian 2016). In this paper, I give only general explanations of children's participation in these pastoral tasks in their daily life to facilitate further analysis of livestock-related EK generation during herding game.
} 
about ten years old, they are able to take initiative roles in daily animal tending, and go day trip herding with peers. Initiatives of children here refer to their independent ability to undertake subsistence related chores, without requests or instructions from adults. This feature distinguishes childhood in pastoral societies from other forms of subsistence. With the aim to understand the EK generation of Maasai children, the daily activities and social participation of Maasai children in a village in Southern Kenya were documented in a previous study (Tian 2016). The group ranch this village belongs to is special and different from many other Maasai group ranches because livestock grazing here still play important roles in local subsistence and the lands are still used and managed communally. Besides attending school, Maasai children in this village actively participate in different types of livestock-related tasks, during which they develop social relations, and continuously produce interactions among children-livestock-biota, which enabled them to further generate livestock-related EK. This finding illustrates the importance of further exploration of children's daily experiences and its relation with EK generation in children in current pastoral social contexts.

\section{The functions of play and work in Maasai society}

Beside active participation in chores, Maasai children also spend considerable time playing with peers. In the Maa language, esiaai (pl. isiaaitin) comes from the verb aisiaai "to serve" and has the meaning of work, chores, labor, and employment; enkiguran (pl. inkiguran), which comes from the verb iguran "to play", has the meaning of playing, game or activities of play (Mol 1996). In the daily life of children, these two types of activities are clearly distinguished. Participating in esiaai incorporates watching, expectation, and sometimes the collaboration of adults, whereas in enkiguran, children intentionally avoid the eyes of adults. They play before, during, and after their daily chores together with peers.

A long and extensive discussion on the significant function of children's play in anthropological and psychological studies reflects the importance of this topic (Lancy et al. 2010; Rogoff 2003; Schwartzman 1978). In psychology, researchers highlighted the importance of children's play in learning and cognitive development. In anthropology, researchers emphasized the non-separable nature of work and play in many non-western societies, and the contributions of these two types of activities to the socialization of children (Chick 2010). In ethnobiology, several researchers 
explored the children-biota relations in small-scale societies where different forms of subsistence exist. For instance, children participate in farming, gardening, hunting and foraging as daily play in farming and hunter-gatherer societies. When playing together, they learn local ethnobiological knowledge and subsistence-related skills that are crucial in their future adulthood (Crittenden 2016; Zarger 2002). Children enjoy participating in these subsistence-like play activities and make economic contributions to their household (Crittenden 2016). They also learn gender roles and social relations (Wenger 1989), and gradually develop their skills in using and making tools in local society (Lancy 2017). Above all, the daily play of children in hunter-gather and farming societies contributes to the cognitive and embodied skills development of children and their social relations, which bring immediate and long-term benefits to the children. However, the social, natural and subsistence contexts are different in pastoral societies, thus, the meaning and functions of play for pastoral children may be different.

In pastoral societies, children play herding and livestock tending during herding game (e.g. Casimir 2010; Ng'asike 2015). They also participate in livestock-related chores independently and contribute to local subsistence (Casimir 2010; Spittler \& Bourdillon 2012). Similarities in ways of herding and livestock separation can be found in both the herding game and the daily chore of livestock grazing. However, there is a lack of detailed documentation on this type of play in pastoral children, and analysis of the correlation of this play with children's work. As such, documentation of the herding game and exploration of its relation with children's chore experiences in livestock-related tasks can contribute to our understanding of children's EK learning in pastoral societies. Using ethnographic data collected in a pastoral Maasai village, this study explores the EK generation of Maasai children during herding game. It attempts to understand the EK generation of children through paying attention to the relation of their work and play, and their practices of the seven livestock-related skills throughout these two types of activities.

\section{STUDY AREA AND METHODOLOGY}

\section{Social and natural environment in the study area}

The study was conducted in a Maasai village near the boundary of Kenya and Tanzania and next to two national parks (NP) in Kenya: the Chyulu Hill NP and the Tsavo West NP. This semi-arid land has two seasons, rainy season (April to June, 
and November to December), and dry season (January to March, and July to October) (Campbell et al. 2003). This area is famous as a wildlife dispersal belt for many animal species such as lion, elephant, hyena, and Cape buffalo (Western 1994).

Since colonial times, wildlife conservation projects and wildlife centered tourism development have had a strong influence on the life of Maasai (Homewood et al. 2009). After the Kenyan government's initiation of the Group Ranch Acts and the promotion of wildlife tourism and agriculture in this area during the 1970s, the Maasai started to live a sedentary life, and since then have experienced land use fragmentation in communal land to individual land (Galvin 2009; Hughes 2006).

The study area was located in a Maasai community where land has not been divided between individuals. The communal use and management of the land actually enabled the children to access natural resources, such as grazing land and water resources through herding, which is different from many other Maasai communities where land has been subdivided and allocated to individuals. Since the 1980s, formal education has been introduced in this area, and the number of children attending school is increasing. In 2015, more than eighty percent of school age children participated in formal schooling both in and outside the village. Besides attending school, they also actively participate in subsistence related daily tasks such as herding, firewood collection and cooking.

\section{Methodology}

This study used participant observation and unstructured interviews as its primary methods for primary data collection. Eleven months of fieldwork in total were undertaken during 2013 to 2015 . Nineteen children from the same homestead in the study area were the focus of data collection and analysis. The data used in this paper was selected from data that was collected during two fieldwork periods in November 2014 to January 2015, and August to October 2015, both included long-term school vacations. During these two periods, the daily activities of children were documented though participant observation of each child from dawn to dusk. Throughout the activities, information was collected from twelve sessions of herding games undertaken by the children either inside or surrounding their homestead. In each session, the time, participants, locations, materials, and the processes of the play activities were documented. These sessions were recorded paying by attention to their correlations with other activities of the children. For instance, when observing 
children's play, how the play has been interrupted, and what children have done before and after the game was also recorded. Moreover, details of these herding games were further compared with the daily chores that children had undertaken during the same fieldwork periods. Of note is that the frequency of this play reduced when children started to go to school after the long-term vacation.

\section{RESUltS}

This section will first, introduce the daily life of Maasai in the study area. An outline of the herding game with details of time, participants, location, materials, and processes will also be given. Finally, analysis of how children interpret the livestock management related skills in the herding game with comparison of their participation in livestock-related pastoral chores will be undertaken. Before going further, it is worth mentioning that (1) all the children have the experiences of participating in one or more types of the above-mentioned seven livestock-related tasks in their daily life ( $c f$. Table 1 below); and (2) although several younger girls participated in the herding game, girls from ten to thirteen years old had never been observed doing so. Rather, they organized their own play such as making house or cooking, usually simultaneously in areas next to children who play the herding game. As this study only focuses on the herding game, it will not investigate other types of play of Maasai children in order to maintain coherence in the analysis.

Table 1: Child participants, their participation in each herding game, and livestock-related daily tasks

$$
(n=19)
$$

\begin{tabular}{|c|c|c|c|c|c|}
\hline & \multicolumn{2}{|c|}{ Boys (age) } & \multicolumn{2}{|c|}{ Girls (age) } \\
\hline & & $\begin{array}{c}\text { Younger } \\
(2-7)\end{array}$ & $\begin{array}{l}\text { Older } \\
(8-10)\end{array}$ & $\begin{array}{c}\text { Younger } \\
(5-9)\end{array}$ & $\begin{array}{c}\text { Older } \\
(10-13)\end{array}$ \\
\hline \multicolumn{2}{|l|}{ Number of Children } & 5 & 5 & 5 & 4 \\
\hline \multicolumn{2}{|c|}{ Herding Game Participation } & Yes & Yes & Sometimes & No \\
\hline \multirow{2}{*}{$\begin{array}{l}\text { Participation in } \\
\text { Livestock-related } \\
\text { Tasks }\end{array}$} & Direct $^{(i)}$ & $1^{\text {(ii) }}, 2,6$ & $1,2,4,6,7$ & $1,2,4,6$ & 1,4 \\
\hline & $\underset{\text { (i) }}{\text { Indirect }}$ & $3,4,5$ & 3,5 & 3,5 & 2,5 \\
\hline \multicolumn{6}{|c|}{$\begin{array}{l}\text { (i) Direct participation refers to children actually performing the task, and taking initiative during } \\
\text { the whole process. Indirect participation refers to children's involvement in a task following the } \\
\text { instructions of others or only through observation. } \\
\text { (ii) The seven livestock-related tasks include: 1) livestock identification and classification, 2) } \\
\text { livestock grouping, 3) reproduction control, 4) milking, 5) diseases management, 6) watering, } \\
\text { and 7) livestock herding. The participation of children in these tasks has been briefly described } \\
\text { in the introduction. }\end{array}$} \\
\hline
\end{tabular}




\section{Chore participation of Maasai children}

The Maasai in the study area live in homesteads of one to eight households. The homestead is fenced with thorn tree branches, and household dwellings are located near the fences in a circle, encircling the livestock corrals in the center of the homestead. People usually maintain a certain area (about $2 \mathrm{~km}$ from neighboring homesteads) surrounding their homestead for the infant and juvenile livestock grazing. Children who live in the same homestead usually undertake chores and play together. During the rainy season, older boys go day-trip herding with peers, and younger children take care of juvenile livestock in the area surrounding their homestead. Girls undertake housework, such as cleaning the house, washing dishes, cooking, and taking care of infant siblings, sometimes with adult women. They also go collecting firewood in areas up to $5 \mathrm{~km}$ away from the village. The firewood they collect is not only used at home, but also in school, or as gifts for friends, neighbors and relatives.

In the dry season, especially during the school vacation, older boys stay in the herding camp and only return to the village with livestock for watering. Once they come back, the younger boys help them accompany the livestock for watering, leaving the older boys with enough time to bathe, eat, change their clothes, and tell the livestock condition to their mother at home. As the infant livestock and their mothers are left in homestead area during the dry season, daily tasks in and surrounding the homestead for younger children are not drastically changed, however, the older girls' firewood collection occurred more frequently and at a further distance from the homestead.

During daily livestock tending, children practiced the seven livestock-related skills according to gender and age differences. Children practice livestock identification, classification, and herd grouping skills when they start to walk. They practice them during milking, herding, and daily checking of the conditions of livestock in and surrounding their homestead. Children younger than five years old watch the newborn and juvenile livestock in areas surrounding the homestead during the day without being accompanied by adults or older children. During the task, they chase away the juvenile herds of neighbors, and frequently gather their livestock together to prevent loss. The Maasai separate the juvenile livestock from their mothers to control the amount of milk available for human use. Younger children who participate in milking are responsible for separating and reuniting each 
of the juvenile livestock with their mothers before, during, and after the adult women or older children express the milk. Elders indicated that two-year old boys are able to distinguish the livestock of their fathers and neighbors before they start to talk.

Reproductive control and disease management of the livestock are initiated by either young men (i.e. moran) or the elders. In daily life, children are encouraged to observe the adults performing castrations and giving treatment to the livestock. During this process, adults are patient in answering any questions from children, and intentionally request the children to run small errands, such as bringing livestock that need to be dealt with from their corrals. Through helping and observing, children become familiar with the symptoms of different livestock diseases. Above all, they repeatedly practiced livestock management skills during milking, watering, and herding; and reported their observations and difficulties to the adults after returning home. With these skills, they are able to lead the livestock to different lands for grazing. Moreover, through herding and watering, they develop individual perceptions of and interactions with the natural environment in different landscapes, thus constantly generating the pastoral EK in daily life. All the play activities of these children occur in a context where children take the initiative for roles in daily livestock tending.

\section{Time, participants, location, and materials for herding game}

Children play the herding game mostly in areas surrounding the homestead, where younger boys simultaneously watch the infant livestock. In Table 2 below, time period, participants, location and materials of each game session are given in detail. Usually, the boys would initiate herding games and invite other children to participate. Children who are free from chores would gather together under the trees surrounding their homestead. Compared with the younger children, the older boys only participated in a few sessions due to limited time, as they are responsible for day-trip herding during the rainy season, and herding in the herding camp during the dry season.

Before they start, the children divide the roles for individuals, designating "herding boys", "young men" (i.e. moran), and "fathers" (the elders). Older boys or those with a good reputation and more experience in livestock tending usually act as "fathers"; those with experience either in herding or watering livestock in real life 
acted as "moran"; and others with less experience in livestock tending in daily chores acted as "herding boys". These boys collect materials as their "livestock" with seasonal differences. Fruits from Solanum incanum L., Solanaceae, kernels of Balanites aegyptiaca (L.) Delile, Zygophyllaceae, and in very few occasions, small round-shape stones were used during the rainy season. During the dry season, dried dung from giraffes, goats and sheep, together with the fruits and kernels are frequently used (cf. Table 2 below). Children sometimes store these materials (except the dung) after one session of play for future use, with the purpose of maximizing the number of their livestock. Increasing the number of one's livestock is quite a similar expectation of every Maasai in local area.

Table 2: Basic information of the documented twelve herding games

\begin{tabular}{|c|c|c|c|c|}
\hline $\begin{array}{l}\text { Session } \\
\text { No. }\end{array}$ & Time Duration & $\begin{array}{l}\text { Number of } \\
\text { Participants } \\
\text { (age categories }^{(i)} \text { ) }\end{array}$ & Location $^{(\mathrm{ii})}$ & Materials $^{(\mathrm{iii})}$ \\
\hline 1 & $\begin{array}{l}2014 / 12 / 118: 25-8: 40 \\
(15 \mathrm{~min})\end{array}$ & $3(\mathrm{~B}, \mathrm{~B}+)$ & $\mathrm{H}$ & $\mathrm{S}, \mathrm{E}$ \\
\hline 2 & $\begin{array}{l}2014 / 12 / 118: 40-9: 30 \\
(50 \mathrm{~min})\end{array}$ & $5(\mathrm{~B}, \mathrm{~B}+)$ & A & $\mathrm{S}, \mathrm{E}, \mathrm{O}$ \\
\hline 3 & $\begin{array}{l}2015 / 1 / 215: 40-16: 05 \\
(25 \mathrm{~min})\end{array}$ & $5(\mathrm{~B}, \mathrm{G})$ & $\mathrm{H}$ & $\mathrm{E}, \mathrm{O}, \mathrm{B}$ \\
\hline 4 & $\begin{array}{l}2015 / 1 / 7 \quad 15: 00-15: 30 \\
(30 \mathrm{~min})\end{array}$ & $5(\mathrm{G}, \mathrm{B}, \mathrm{B}+)$ & A & $\mathrm{E}, \mathrm{O}, \mathrm{Dl}$ \\
\hline 5 & $\begin{array}{l}2015 / 1 / 813: 30-13: 50 \\
(20 \mathrm{~min})\end{array}$ & $4(\mathrm{~B}, \mathrm{G})$ & A & $\mathrm{E}$ \\
\hline 6 & $\begin{array}{l}2015 / 1 / 815: 40-16: 20 \\
(40 \mathrm{~min})\end{array}$ & $11(\mathrm{~B}, \mathrm{G})$ & $\mathrm{H}$ & hs \\
\hline 7 & $\begin{array}{l}2015 / 1 / 1317: 20-18: 15 \\
(55 \mathrm{~min})\end{array}$ & $6(B, G)$ & A & $\mathrm{S}, \mathrm{E}$ \\
\hline 8 & $\begin{array}{l}2015 / 1 / 1810: 50-11: 30 \\
(40 \mathrm{~min})\end{array}$ & $5(\mathrm{~B}, \mathrm{~B}+)$ & A & $\mathrm{E}$ \\
\hline 9 & $\begin{array}{l}2015 / 1 / 258: 30-10: 00 \\
(90 \mathrm{~min})\end{array}$ & $5(\mathrm{~B}, \mathrm{G})$ & A & $\mathrm{E}$ \\
\hline 10 & $\begin{array}{l}2015 / 2 / 229: 30-10: 20 \\
(50 \mathrm{~min})\end{array}$ & $7(\mathrm{G}, \mathrm{B}, \mathrm{B}+)$ & A & $\mathrm{S}, \mathrm{E}, \mathrm{O}, \mathrm{hs}$ \\
\hline 11 & $\begin{array}{l}2015 / 8 / 219: 05-9: 35 \\
(30 \mathrm{~min})\end{array}$ & $5(\mathrm{~B}, \mathrm{G})$ & A & $\mathrm{Dg}, \mathrm{E}$ \\
\hline 12 & $\begin{array}{l}2015 / 8 / 248: 50-10: 15 \\
(85 \mathrm{~min})\end{array}$ & $8(\mathrm{~B}, \mathrm{G})$ & A & Dg, B \\
\hline Mean & $44.2 \mathrm{~min}$ & 6 & - & - \\
\hline \multicolumn{5}{|c|}{$\begin{array}{l}\text { Age categories include: B: younger boys; B+: older boys; G: younger girls, as } \\
\text { explained in Table 1. } \\
\text { (ii) Locations include H: inside homestead; A: areas surround the homestead. } \\
\text { (iii) Materials include: S: stones; E: fruits from entulele (Solanum incanum L.); O: fruit } \\
\text { kernels of osalagi (Balanites aegyptiaca (L.) Delile); B: plastic bottle; Dl: dried dung } \\
\text { of goats and sheep; Dg: dried dung of giraffe; hs: herding sticks. }\end{array}$} \\
\hline
\end{tabular}




\section{How to play the herding game}

\section{Make a "herding camp" and grouping the "herds"}

When the game starts, "fathers" construct the "herding camp", with a "corral for adult cattle", a "pen for calves", a "corral for adult goats and sheep", and a "pen for juvenile goats and sheep". They also make gates for different herds heading in different directions ( $c f$. Figure 1 below). Each "father" would construct his own "herding camp", of varying size and shape.

Figure 1: Herding camp with different herds in the game (session No. 4)



Children practiced livestock identification and grouping in this game. They identify and group the collected materials as different "herds" according to their type, size, color, and shape; then, settle them in the "herding camp" accordingly. Sometimes, from the collected fruits of Solanum incanum L., Solanaceae, children select the biggest or the rare yellow color ones to be the "bull". They separate the common green ones to be "calves" or "adult cattle" according to size. They gave names to their "oxen", which not only mimic cattle names from their homestead, but also use the ones they have heard from others. There were also occasions that children crawled on the ground and pretended to be "livestock" themselves. For instance, in session No. 6, except for two younger boys who acted as "herding boys", the other children put fresh cow dung on the bottom of their skirt and trousers, and crawled on the ground pretending to be a "bull" and "female cattle". During their play, they joyfully reviewed the livestock identification, classification, and grouping, which they have learned during daily chores. 


\section{Simulating herding routes, water points, and herding}

After all the "livestock" are grouped and settled in their "corrals", the "father" then divides the herding tasks between the "herding boys" and the "morans". Usually, the "herding boys" are responsible for herding the different "herds" (i.e. cattle, calves, adult goats and sheep, and juvenile goats and sheep), and the "morans" for making "water points". If there are still participants who do not have roles in the game, there would either have more "herding boys", often an older child with a younger child, "go herding" in pairs; or even have children representing "lions" or "officers from the KWS (Kenya Wildlife Service)" (cf. Figure 2 below). For instance, in session No. 4, before leading the "herds" out, the "herding boys" first made "herding routes" with "hills", "mountains", and "grazing land" following the suggestions of the "fathers". At the same time, the "moran" started to construct "water points". They constructed different "routes" for different "herds", and kept certain distance among these "routes" to avoid mixing the "livestock". During the rainy season, they chose a small piece of grass near the herding camp for using as their constructed "grazing land".

Construction of "water points" was observed mostly during the dry season. Children made "water points" with similar characteristics as real ones. Their "water point" had one side for pumping and lifting the "water" (i.e. the sand, or urine) up, and the other side with a channel for "livestock" to walk in and take the "water". In all the sessions, some children had experiences of accompanying the livestock to water points in daily life. Playing together and reviewing daily tasks enabled all the children to communicate and transmit their skills and chore participation experiences.

During "herding", the "herding boys" usually lead their "herds" to the "grazing land" or "water points" along the "herding routes" they constructed. Crouching on the ground, children use hands to push the "livestock" to move forward. They frequently check the movements of their peers. While whistling towards their own "livestock", they kept distance with others" "herds". They also tried to avoid losing "livestock" (i.e. prevent the play materials from being lost in the sandy ground). The "herding boys" sometimes inform each other, for instance, which "routes" are too sandy, or where they had encountered "lions" (i.e. either insects on the ground, or being acted by other children). With these notifications from others, the "herding boys" in several sessions re-constructed and changed their "herding routes" 
directions. In this playground, children recalled the herding and livestock watering experiences they had in daily chores in detail, such as the conditions of the natural environment, movements of wildlife and livestock, and the social relationships among people.

Figure 2: Individual roles and performance in the herding game (session No. 4)

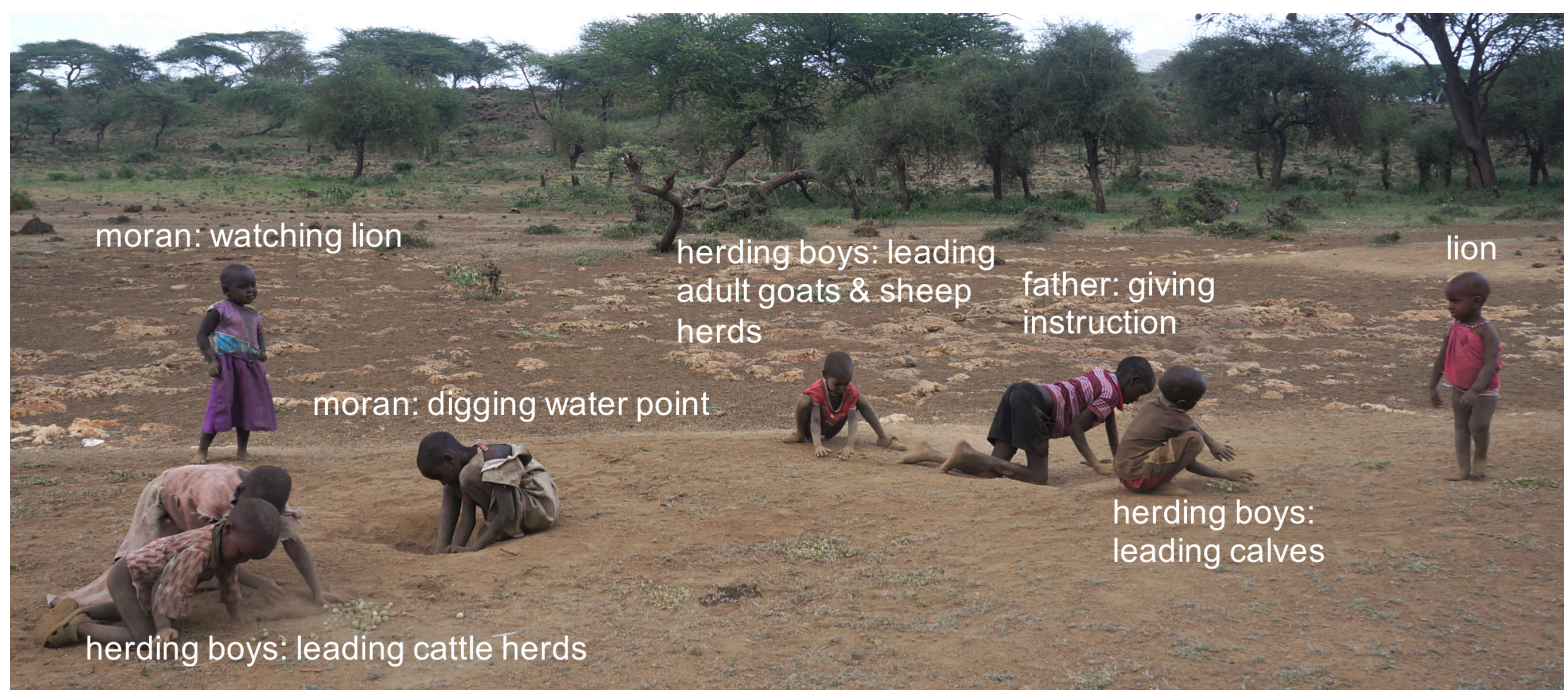

\section{"Watering" and "livestock treatment"}

When taking the "livestock" for "watering", children separated the "herds" into small groups. They stopped the small groups that had been led to "water points" on one side, whilst waiting for herds finishing watering on the other side. The herds that were waiting to "take water" were well managed and watched by the "herding boys". For instance, children frequently confirmed the condition of the "livestock", for example either they had lost the "livestock", or they had mixed their "herd" with others'. In session No. 12, children gathered their urine in a plastic bottle to pour and wet all the "livestock" that came to the "water point" in turn. After "watering" them, the "father" reconfirmed if all the "livestock" had taken enough "water" (i.e. in wet conditions). The "livestock" that he thought might have not taken enough "water" (i.e. in half-wet condition) were sent back to the "water point" again. These scenes had been frequently observed during real livestock watering. Children who participated in livestock watering in real life vividly repeated the process of this task and recalled the contexts within which this task had been undertaken.

Children also treated "livestock" for diseases during this game. For instance, in session No. 6, some children pretending to be "livestock", were initially resistant to move and mimicked weak mooing. "Herding boys" then made plans to give 
injections to them. They caught the "cattle", tied its legs and handled its "horns" (i.e. the ears of children). The "cattle" that received injections were restive: jumping, running and defending themselves from being caught by "herding boys", especially the "bull". The "herding boys" stopped the "cattle" one by one, caught its arms, legs and body tightly, and quickly injected the neck of the "animal". After being injected in the neck, these "cattle" would lay down on the ground, mimicking mooing like crying. Several studies highlighted pastoralists' careful observation of the illness symptoms of livestock (e.g. Jacob et al. 2004; Ohta 1982). This can be also found in the ways that children interpret the illness treatment of livestock in their play. As in session No. 6, children accurately interpreted the reactions of the livestock before, during, and after the treatment through their acting performances.

\section{Disturbances during and ending the herding game}

One session of herding game continued on for fifteen minutes to one and half hours. Children sometimes shifted this game to other play activities, such as tree climbing or singing. Besides, these herding game sessions were sometimes disrupted when they were requested to undertake errands by adults (e.g. shopping, washing dishes, and babysitting) or having food. When this occurred, children did not always stop their play straightaway, and often chose the timing to stop. They also intentionally watched the livestock while playing this game. For example, during four sessions they stopped the herding game for a while to gather the juvenile livestock that had moved far away; and carefully prevented the mixing of their juvenile livestock with others' that passed by. In six sessions, they stopped to accompany the livestock to the water point when they saw them coming back from the herding camp. Above all, shifting from playing herding to real livestock tending tasks, or vice versa, were largely decided and managed by the children themselves regardless of whether the adults had given instructions or not.

\section{DISCUSSION}

Ingold and Kurttila (2000: 193) contend that traditional knowledge can be better denoted with the concept of skill, which is property of "the whole system of relations constituted by the presence of the agent in a richly structured environment". They consider the skill "is grounded in an active, perceptual involvement" with practitioners, and "people develop their own ways of doing things, but in environmental contexts structured by the presence and activities of predecessors". 
With regard to this notion, for further discussing the EK generation by children during the herding game, beside the individual participation in described EK practices, one needs first, to understand the social context within which children are able to continue the EK practices. It is necessary to also understand the interests of children, for instance their concern, attention; and their interactions with each other when they undertake different daily activities. Focusing on the playing activities of children can especially serve the analysis.

This section focuses on the EK generation of children during playing activities with consideration to the correlation between work and play. First, the social and natural environmental contexts within which children take initiatives in their chores and play will be reviewed. Second, analysis of the continuation of EK practices of children during play compared with their chore participation will be undertaken. Last, the interactions of children during the herding game will be analyzed via their communication and exchange during the chore experiences. This will facilitate understanding of the livestock-related EK generation of Maasai children during play.

\section{Social and natural environmental contexts}

With reference to the gender-age roles, children in Maasai society are expected to participate in livestock tending from an early age (Grandin 1991; Spencer 2003). The positive evaluation of adults to children's chore participation can be also observed through their ways of requesting children's chore participation and their attitude towards children's play. When children played the herding game, adults frequently called them to attend to tasks and chores. However, an instant change from play to undertaking chores was not strictly enforced. The adults showed their respect and trust of the children; by telling them their needs (i.e. children's participation in chores), but letting the children choosing when and how to undertake the requested tasks and chores. It is because of this expectation and trust from adults that children are able to access different pastoral EK and repeat related skills with peers, both during play and work. The gender-age labor division and local evaluations concerning these roles have supported and encouraged the livestock-related EK generation of children throughout chores and play in Maasai society.

The continuation of children's participation in livestock related chores is also strongly linked to the accessibility of Maasai to different grazing lands in the study area. As inhabitants of one of the group ranches where the land is still managed 
communally, the Maasai in the study area are able to keep their livestock, and manage them with the collaboration of homestead members following gender-age roles and seasonal changes in grazing land. Within this specific social context, children are able to explore the seasonal natural environment with their livestock, through which they generate EK with peers. During the herding game, the livestock-related EK is generated, as the reflection of children's experiences and curiosity in the current social and natural environmental contexts of Maasai in the study area. This situation may differ in other Maasai communities where the land has been totally subdivided into individual plots, or where children's participation in livestock herding is strongly discouraged due to formal education. Without accessibility to the land and social contexts that allow the continuation of children's participation in livestock herding, the herding game may become totally different and may no longer contain details of grazing lands, herding routes, livestock watering processes or the encountering of dangerous animals.

\section{Continuation of ethnobiological knowledge practices during chores and the herding game}

As mentioned above, Maasai children take initiative roles in livestock tending in local society (Grandin 1991). In the study area particularly, besides attending school, they actively participate in livestock related chores and continued with these even during school days (Tian 2016). When conducting chores, they constantly practiced the seven livestock-related tasks, i.e. livestock identification and classification, livestock grouping, reproduction control, milking, disease management, livestock watering, and herding, all of which have been repeated in the herding game.

As previous findings have shown, children practiced livestock identification and classification, livestock group, and milking through either direct or indirect participation in daily livestock tending chores since they began to walk (Tian 2016). During the herding game, except "milking", the other skills have been frequently employed. During daily chores, children observe reproduction control and disease management undertaken by the adults, and gradually get involved in this chore through running errands. When playing the herding game, they included "reproduction control" and "disease management" on a few occasions; and were curious in regard to the reactions of the livestock before, during, and after the treatment. Interpreting this careful observation in the herding game, children vividly recalled livestock treatment mimicking interactions between the livestock and adults, 
including the reactions of the livestock they had observed during the chore.

Children, especially boys, are familiar with the livestock in their homestead and skilled in livestock identification, classification and grouping - participate in livestock watering and herding. During livestock watering, they met livestock from different homesteads, and learned how to collaborate with different people. During herding, their expertise in livestock identification, classification, and grouping, these children visited grazing lands in different locations, and progressively generated EK in the ongoing human-livestock-biota interactions and relations. This in-situ EK generation during daily tasks have been reviewed in the herding game with construction of "mountains", "grazing lands", "herding routes", and "water points"; and the metaphorized "dangerous wild animals", "herds", "children" and "adults". Above all, livestock related EK has been continuously repeated throughout chores and play in the daily life of Maasai children.

\section{Processing children-livestock-biota interactions during play}

Schwartzman's study (1978), used the concept of "metacommunication" from Bateson (1972) to emphasize the feature of make-believe as a kind of communication, through which, paradoxical statements concerning the persons, objects, activities and situations in real life have been used in communication among participants during play. In the herding game, children acted as "adults", "morans", "herding boys", "cattle", and sometimes "government officers", and performed different roles of people in local society. As mentioned above, these children had different experiences in real life, participating in livestock-related daily tasks. During the herding game, they communicated with each other using paradoxical messages concerning what had happened during their livestock-related daily chores. This kind of communication may contribute to livestock-related EK transmission among peers.

Older boys, or children with more experience in livestock tending during chores acted as "fathers" in the herding game. When undertaking livestock-related chores, these older children gave instructions to the children with less experience in these tasks. Acting as the "father", older boys or children with more experiences were respected by those who acted as "young men" and "herding boys". The "fathers" as the most experienced children in actual livestock-related daily tasks were entrusted to give instructions to their peers during the herding game. An individual child's perception of another's skill in daily livestock caring related tasks, and their 
perceptions of the valued and respected behaviors in current Maasai society have been confirmed in the acting out of different social identities during play.

During daily chores, children constantly generate skills and experiences and they interpreted them enjoyably during herding games. The boys who went to water the livestock organized the herding game including the "crowdedness of herds waiting for water", the careful check of each "livestock" to determine if they had "drunk" enough or not. Children communicated the watering process with each other by digging holes in the ground and wetting small pieces of dung with water or urine. Transmission of this message enabled the learning of livestock watering especially among children who have not yet participated in these tasks. Most of the children who went herding in daily life had had the painful experience of losing livestock. When losing a sheep or a goat, despite being blamed by adults, boys sometimes were mortified enough to hide themselves and cry. During herding game this grievous fault became easy to express through organizing similar scenes but with a happier ending.

Through the herding game, children express their chore experiences to others in an enjoyable way. During daily chores, their EK generation accompanies several uncertainties and occasionally regrettable experiences such as encountering lions or losing livestock. Transmission of this kind of onsite experiences through playing on the one hand enabled the boys to speak about their own experiences, and conversely on the other hand enabled the other children to learn from the experiences of others. As younger children who do not participate in herding in daily life also join this game, this playing experience for them can be understood as the beginning of the accumulation of their own relations with livestock and biota.

\section{CONCLUSION}

This paper focused on the herding game of Maasai children and analyzed pastoral children's EK generation during play considering the correlation of children's chores and play in daily life. Through participant observation, this study focused on nineteen children in a Maasai village where livestock still play important roles in local subsistence, and the lands are still managed communally. Despite attending the local school, children in this village are encouraged to and indeed take an active role in pastoral subsistence through participation in herding and other livestock-related chores. Following the gender-age roles of labor division in local society, they begin to 
participate in daily livestock care with peers from an early age. During these daily chores, they practiced the seven livestock tending skills and empirically continued the children-livestock-biota interactions, thus generating the livestock-related EK.

The herding game was played within the daily contexts of children and during play, children recalled their livestock tending experiences and continued the EK practices. Through reproducing previous human-livestock interactions with the in-situ social relations and conditions, as well as the natural environment contexts present during the chores, children communicated with each other and transmitted the EK in an enjoyable way. During play, older children who are more experienced in daily livestock tending organized the play, through which they could express their livestock tending knowledge derived from daily chores. This way of playing enabled the children with less experience in chores with the chance to communicate and rehearse the livestock-related daily tasks before taking on the same actual responsibility. Results from this study first highlight the EK learning of Maasai children through daily play and chore participation; second, they emphasize the importance of children's accessibility to the land, which contribute to the continuation of their EK learning. Also, they encourage further investigation of EK generation among children through their daily play, and argue the necessity to pay attention to the correlation of this type of activity with other daily experiences of children in other social and natural environment contexts.

\section{BIBLIOGRAPHY}

BATESON G. 1972 Steps to an ecology of mind. New York : Ballantine Book.

BeKure S., LeeuW P.N., Grandin B.E. \& Neate P.J.H. (eds.) 1991 Maasai herding : An analysis of the livestock production system of Maasai pastoralists in Eastern Kajiado District, Kenya. Addis Ababa : International Livestock Centre for Africa.

Bussman W.R., Gilbreath G.G., Solio J., Lutura M., LutuluO R., Kunguru K., WoOd N. \& MAtHENGE S.G. 2006 «Plant use of the Maasai of Sekenani valley, Maasai Mara, Kenya », Journal of Enthnobiology and Ethnomedicine 2(22) : 1-7.

BUTT B. 2010 «Seasonal space-time dynamics of cattle behavior and mobility among Maasai pastoralists in semi-arid Kenya », Journal of Arid Environments 74(3) : 403-413.

BUTT B. 2011 «Coping with uncertainty and variability: The influence of protected areas on pastoral herding strategies in east Africa », Human Ecology 39(3) : 289-307. 
CAMPBell J.D., LuSCH D.P., SMUCHER T. \& WANGUI E.E. 2003 Root causes of land use change in the Loitokitok Area, Kajiado District, Kenya. LUCID Working Paper Series Number 19. Nairobi: International Livestock Research Institute.

CASIMIR M.J. 2010 Growing up in a pastoral society: Socialization among Pashtu nomads in Western Afghanistan. Koln : Druck and Bindung.

CHICK G. 2010 «Work, play, and learning » (119-144), in D.F. Lancy, J.C. Bock \& S. Gaskins (eds.) The anthropology of learning in childhood. Lanham : AltaMira Press.

CRITTENDEN A.N. 2016 "Children's foraging and play among the Hadza: The evolutionary significance of 'work play'» (155-172), in C.L. Meehan \& A.N. Crittenden (eds.) Childhood: origins, evolution, and implications. Santa Fe : School for Advanced Research Press.

De PINHO M.J.F.L.R 2009 'Staying together': People-wildlife relationships in a pastoral society in transition, Amboseli ecosystem, Southern Kenya. Fort Collins : Colorado State University, PhD thesis.

FRATKIN E. 1989 «Household variation and gender inequality in Ariaal pastoral production : Results of a stratified time-allocation survey », American Anthropologist 91(2) : 430-440.

GALATY J. 1989 "Cattle and cognition: Aspects of Maasai practical reasoning » (215-230), in J. Clutton-Brock (ed.) The walking larder: Patterns of domestication, pastoralism, and predation. London: Unwin Hyman Ltd.

GALVIN K. 2009 « Transitions: Pastoralists living with change », Annual Review of Anthropology 38 : 185-198.

GRANDIN B.E. 1991 «Chapter 3: The Maasai : Socio-historical context and group ranches» (21-39), in S. Bekure, P.N. Leeuw, B.E. Grandin \& P.J.H. Neate (eds.) Maasai herding. An analysis of the livestock production system of Maasai pastoralists in Eastern Kajiado District, Kenya. Addis Ababa : International Livestock Center for Africa.

Homewood K. \& Rodgers W.A. 1991 Maasailand ecology. Cambridge : Cambridge University Press.

Homewood K., Kristjanson P. \& TRENCH P.C. (eds.) 2009 Staying Maasai? Livelihoods, conversation and development in East African rangelands. New York : Springer.

HUGHES L. 2006 Moving the Maasai : A colonial misadventure. Hampshire : Palgrave Macmillan.

INGOLD T. 2011 Being alive, essays on movement, knowledge and description. London : Routledge.

INGOLD T. \& KURTTILA T. 2000 «Perceiving the environment in Finnish Lapland », Body \& Society 6(3-4) : 183-196.

JACOB M.O., FARAH K.O. \& EKAYA W.N. 2004 «Indigenous knowledge : The basis of the Maasai ethnoveterinary diagnostic skills », Journal of Human Ecology 16(1) : 43-48. 
KIRINGE W.J. 2005 «Ecological and anthropological threats to ethno-medicinal plant resources and their utilization in Maasai communal ranches in the Amboseli region of Kenya ", Ethnobotany Research \& Applications $3: 231-241$.

KONAKA S. 2005 The anthropology of pastoral dual economy: Ethnography of Samburu, Kenya (in Japanese). Kyoto : Sekaishisousya.

KONAKA S. 2010 «Metaphorical projection and integrated cognitive systems: The Samburu in North Central Kenya » (63-73), in F. Stammler \& H. Takakura (eds.) Good to eat, Good to live with : Nomads and animals in Northern Eurasia and Africa. Sendai : Center for Northeast Asian Studies, Tohoku University.

LANCY D. 2017 «Homo faber juvenalis: A multidisciplinary survey of children as tool makers/users », Childhood in the Past 10 : 72-90.

LANCY D., BOCK J. \& GASKINS S. 2010 The anthropology of learning in childhood. Lanham : AltaMira Press.

LitTle M.A., HudSON R.D. \& MCCABE J.T. 1999 «Ecology of south Turkana » (43-76), in M.A. Little \& P.W. Leslie (eds.) Turkana herders of the dry savanna ecology and biobehavioral response of nomads to an uncertain environment. Oxford : Oxford University Press.

Meguro Y. 2014 The wandering 'coexistence' and The Maasai : From the field of wildlife conservation in Kenya (In Japanese). Tokyo : Shinsensha.

Messing S.D. 1985 Highland plateau Amhara of Ethiopia. New Haven: Human Relations Area Files.

MoL F. 1996. Maasai: Language and Culture. Narok : Mill Hill Missionary.

NG'ASIKE J.T. 2015 "Take me to the (dry) river: Children's play in Turkana pastoralist communicates of Kenya » (103-116), in J.L. Roopnarine, M.M. Patte, J.E. Johnson \& D. Kuschner (eds.) International perspectives on children's play. Maidenhead : Open University Press.

ОвА G. 2012 « Harnessing pastoralists' indigenous knowledge for rangeland management : Three African case studies », Pastoralism: Research, Policy and Practice 2(1) : 1-25.

OHTA I. 1982 « Man-animal interaction complex in goat herding of the pastoral Turkana », African Study Monographs, Supplement Issue $1: 13-41$.

OHTA I. 1984 «Symptoms are classified into diagnostic categories: Turkana's view of livestock diseases », African Study Monographs, Supplement Issue 3 : 71-93.

OHTA I. 1987 «Livestock individual identification among the Turkana: The animal classification and naming in the pastoral livestock management », African Study Monographs 8(1) : 1-69.

ROGOFF B. 2003 The cultural nature of human development. Oxford : Oxford University Press. 
SATO S. 1980 « Pastoral movements and the subsistence unit of the Rendille of northern Kenya : With special reference to camel ecology ", Senri Ethnological Studies 6 : 1-78.

SCHWARTZMAN H.B. 1978 Transformations : The anthropology of children's play. New York: Plenum Press.

SPENCER P. 2003 Time, space, and the unknown. New York : Routledge.

SPITTLER G. 1998 Hirtenarbeit. Die Welt der Kamelhirten und Ziegenhirtinnen von Timia. Köln: Rüdiger Köppe.

SPITTLER G. \& BOURDILLON M. 2012 African children at work: Working and learning in growing up for life. Wien : LIT Verlag.

SUN X. 2005 «Dynamics of continuity and change in pastoral subsistence among the Rendille in Northern Kenya: With special reference to livestock management and response to socio-economic change », African Study Monographs, Supplement Issue 31 : 1-94.

TIAN X. 2016 « Day-to-day accumulation of indigenous ecological knowledge : A case study of pastoral Maasai children in Southern Kenya », African Study Monograph 37(2) : 75-102.

WENGER M. 1989 «Work, play, and social relationships among children and sibling caretaking » (91-114), in D. Belle (ed.) Children's social networks and social supports. New York : Wiley.

WESTERN D. 1994 «Ecosystem conservation and rural development: The case of Amboseli » (15-52), in D. Western, R.M. Wright \& S.C. Strum (eds.) Natural connections: Perspectives in community-based conservation. Washington : Island Press.

ZARGER R.K. 2002 Children's ethnoecological knowledge : Situated learning and the cultural transmission of subsistence knowledge and skills among Q'eqchi' Maya. Athens: University of Georgia, Doctoral dissertation. 